\title{
Niezbędność duchowości \\ dla stawienia czoła kryzysowi ekologicznemu: przesłanie encykliki Laudato si'
}

W encyklice Laudato si' w związku z palącą globalną potrzebą stawienia czoła kryzysowi ekologicznemu papież Franciszek jeden $\mathrm{z}$ sześciu rozdziałów poświęcił kształtowaniu ludzi i duchowości ekologicznej ${ }^{1}$. Są to numery 202-245, czyli 43 spośród wszystkich 245, ok. 5200 wyrazów, 37800 znaków (licząc także spacje) na ok. 34 ooo wyrazów, 250900 znaków (uwzględniając również spacje), które składają się na całą encyklikę Laudato si'. Już przytoczone liczby sugerują, że papież Franciszek chce zwrócić uwagę na pozytywne znaczenie duchowości dla skutecznego stawienia czoła kryzysowi ekologicznemu.

\section{Laudato si’ o Bogu}

W rozumieniu chrześcijańskim zasadniczym „elementem” duchowości są związki z Bogiem. W Laudato si' na ok. 34 ooo wyrazów, biorąc pod uwagę zmienność form gramatycznych, termin Bóg występuje ok. 140 razy, Pan w odniesieniu do osoby Bożej - ok. 30 razy, Trójca, by mówić o Trójcy Świętej, ok. 5 razy, Stwórca ok. 20 razy, Chrystus ok. 10 razy, Jezus ok. 20 razy, Duch, by mówić o Duchu Świętym, ok. 5 razy. Papież Franciszek w omawianym

1 Franciszek, enc. Laudato si' poświęcona trosce o wspólny dom, 24.05.2015, s. 193n, https:// w2.vatican.va/content/dam/francesco/pdf/encyclicals/documents/papa-francesco_20150524_enciclicalaudato-si_pl.pdf, 18.06.2016 [dalej: Ls]. 
dokumencie o Bogu pisze częściej (np. nr 50). Dla porównania: słowo ekologia zostało tam użyte ok. 30, a dom ok. 15 razy. Relacje Bóg-stworzenia encyklika wiąże z całościowym spojrzeniem na świat. Przy czym daje się tu zauważyć następującą sekwencję: 1) przed aktem stwórczym; 2) doczesność od aktu stwórczego przed wtargnięciem w dzieje grzechu i jego negatywnych skutków; 3) doczesność negatywnie kształtowana przez grzech i zarazem przede wszystkim nadal będąca przedmiotem skutecznej miłości ze strony miłosiernego Boga; 4) wieczność zbawienia (np. Ls, odpowiednio $\mathrm{nr} 77,65,66,243$ ). Podobne spojrzenie przekazuje np. Ef 1, 3-14 i Kol $1,12-20^{2}$.

To, co Laudato si przekazuje na temat Boga, spotkania z Nim, Jego planów i działania, pierwsze i ostatnie słowa tej encykliki znamiennie ujmują w ramy skierowanego do Niego uwielbienia, dzięki czemu nasuwa się wniosek, że jednoznacznie mamy do czynienia z prymatem łaski, miłości i miłosierdzia. "Laudato si', mi Signore - bądź, Panie mój” (Ls, nr 1). „Pochwalony bądź, Panie! Amen” (Ls, Modlitwa za nasza ziemię, zakończenie). Powołując do życia swe stworzenia i dalej opiekując się nimi, Bóg urzeczywistnia swoje marzenia, „projekt pokoju, piękna i pełni” (LS, nr 50). On, powodowany miłością (LS, nr 77), powołał do istnienia wszystko jako bardzo dobre (Ls, nr 65). Cały wszechświat został stworzony jako otwarty „na transcendencję Boga, w ramach której [...] się rozwija” (Ls, nr 79). Zarazem Bóg całkowicie wszechświat wypełnia (LS, nr 233). By rozpoznać Jego działanie, człowiek otrzymał do dyspozycji drogę "ze świata zewnętrznego do wewnętrznego", ale też „wyjście na spotkanie z Nim we wszystkim", i dotyczy to nawet kontemplacji (Ls, nr 233). Jak pisze papież, „cała natura” to miejsce, które Bóg wybrał, żeby w nim być obecnym, i to tak dalece, że ona Boga objawia. Przez swe zamieszkiwanie w każdym stworzeniu Bóg wzywa, by z Nim być razem (Ls, nr 88). Doświadczenie stwórczej, życiodajnej mocy Boga oraz bycia „wobec Niego i z Nim” pobudza do uwielbienia Go (LS, nr 72). W takim razie „nieskończony dystans” między Bogiem i światem doczesnym, między właściwym Bogu istnieniem pełnym a istnieniem ograniczonym bytów stworzonych znajduje w spotkaniu i bliskości ważną interpretację (Ls, nr 88). Boża bliskość i wola wchodzenia w relacje to przejaw ustawicznej, doskonałej miłość ze strony Boga, dotyczącej także materialnego wymiaru rzeczywistości (LS, nr 77, 84). Miłość ta znajdzie swój ostateczny wyraz w darze wiecznej pełni życia (LS, nr 243-244). Bóg daje się

Zob. B. Byrne, A Pauline Complement to „Laudato si”, „Theological Studies (Online)” 77 (2016) nr 2, s. 308n. 
poznać jako Ten, który stwarza, wyzwala, zbawia, prowadzi do pełni istnienia. Te wymiary Jego działania stanowią jedno i są ściśle wzajemnie powiązane (Ls, nr 73, 243-245) ${ }^{3}$.

Bóg jest aktywny, kochając i będąc obecnym w świecie. Nie jest to bynajmniej aktywność sporadyczna, ograniczająca wolność czy aktywność istot stworzonych. Bóg „ze wszystkimi stworzeniami” pozostaje w relacjach o charakterze ojcowskim, każde stworzenie ,jest ważne w Jego oczach” i Chrystus o tym „przypomniał ze wzruszającą czułością” (Ls, nr 96). Jest On obecny, np. „pobudzając nowe drogi” (LS, nr 238). Jego działanie jest skuteczne. „Jeśli Bóg potrafił stworzyć wszechświat z niczego, to może też interweniować w tym świecie i pokonać wszelkie formy zła” (LS, nr 74). „Nie ma systemów, które całkowicie zniweczyłyby [...] zdolność do reakcji, jaką Bóg nieustannie wzbudza w głębi naszych serc" (LS, nr 205). Na pozytywny charakter świata stworzonego składa się także to, że ze szczodrością Bóg zawarł w nim różnorodne dobra. Powierzył On taki właśnie świat ludziom. Nie mamy tu bynajmniej do czynienia z zezwoleniem, by ludzie wyzyskiwali czy niszczyli świat, lecz z powierzeniem opieki (Ls, $\mathrm{nr} 67,78$ ). Bóg pozostał wierny tym zamiarom także wtedy, gdy w dzieje świata wtargnął grzech (Ls, $\mathrm{nr} 2$, 4; zob. też $\mathrm{nr}$ 117). Bóg kontaktuje się skutecznie z ludźmi (LS, nr 70, 77; zob. też nr 12, 85, 86) 4 $^{4}$ Udzielone ludziom prawo, by odpowiedzialnie korzystali z dóbr tego świata, stanowi jedno z wezwań, by uznali oni, „że inne istoty żywe mają właściwą sobie wartość wobec Boga” (Ls, nr 69)5. On zaprasza i uzdalnia ludzi do współpracy z sobą (LS, nr 80, 102; zob. 1 Kor 15, 10). Chrystus jest w stanie „nauczyć troski, motywować” ludzi „do wielkodusznej pracy z czułością, aby chronić ten świat, jaki powierzył nam Bóg” (Ls, nr 242). Z woli Boga relacje międzyludzkie są nieoddzielne od związków ludzi z innymi stworzeniami. „Bóg złączył nas tak ściśle z otaczającym światem, że pustynnienie ziemi jest niejako chorobą dotykającą wszystkich, i możemy ubolewać nad wymarciem jakiegoś gatunku jak nad swoistym okaleczeniem" (Ls, nr 89). Zbrodnia przeciw naturze jest jednocześnie zbrodnią przeciw ludziom i grzechem, gdy chodzi o relacje z Bogiem

\footnotetext{
3 Zob. np. V. Maraldi, Lo Spirito Creatore e la novità del cosmo. Postfazione di L. Galleni, Milano 2002, s. 9 .

4 Zob. Benedykt xvi, Katecheza, 9.11.2005, [w:] „L'Osservatore Romano” (wyd. pol.) 27 (2006) nr 3, s. 39 .

5 Zob. Katechizm Kościoła Katolickiego, Poznań 2002, nr 2416.
} 
(LS, $\mathrm{nr} 8)^{6}$. Stosunki między stworzeniami z Jego woli należy kształtować, stosując się do stanu sprzed wtargnięcia grzechu w dzieje: czyli mamy do czynienia z nieanulowanym prymatem łaski, świętości, życia, pomyślności (LS, nr 5).

Bóg ma i realizuje swe plany co do stworzeń nie tyko, gdy chodzi o doczesność. On ofiarowuje przyszłość eschatologiczną: „wszystko, co jest w nim [tzn. w doczesnym domu] dobre, zostanie zebrane na niebiańskiej uczcie" (LS, nr 244). Podobnie prawie 50 lat wcześniej wypowiedział się Sobór Watykański II $^{7}$. To otwarcie eschatologiczne jest ściśle związane z Chrystusem, z misterium wcielenia i z misterium wielkanocnym, z Jego skutecznym działaniem już w doczesności: „wszystkie stworzenia materialnego wszechświata odnajdują swój prawdziwy sens w Słowie Wcielonym, ponieważ Syn Boży w swojej osobie przyjął materialny wszechświat, w który wprowadził zalążek ostatecznej transformacji” (LS, nr 165) . Gdy chodzi o papieży, to takie nauczenia znajdziemy także u św. Jana Pawła II ${ }^{9}$. Jak rozumieć skalę tego misterium, papież Franciszek wyjaśnia następująco: „stworzenia tego świata ukazują się nam już nie jako rzeczywistości czysto naturalne, ponieważ Zmartwychwstały tajemniczo je otacza i ukierunkowuje ku pełni. Te same dzikie kwiaty i ptaki, które podziwiał swymi ludzkimi oczami, są obecnie wypełnione Jego jaśniejącą obecnością" (LS, nr 10o). Bóg sprawił, że doczesność jest bardzo dynamiczna, jest ona z Jego daru wspólnym pielgrzymowaniem społeczności stworzeń. Na wartość i siłę doczesnego domu składa się to, że jest on w drodze do wiecznego, doskonałego domu Ojca (zob. J 14, 1-4). „My sami nie jesteśmy ostatecznym celem wszystkich innych stworzeń. Wszystkie zmierzają wraz z nami i przez nas ku ostatecznemu kresowi, jakim jest Bóg w transcendentalnej

C. P. Arand, Tending our common home: Reflections on „Laudato si”, „Concordia Journal” 41 (2015) nr 4, s. 308n; W. Jenkins, Ecologies of Grace: Environmental Ethics and Christian Theology, Oxford 2013, s. 102.

Zob. Sobór Watykański II, konst. duszpasterska Gaudium et spes o Kościele w świecie współczesnym, [w:] Sobór Watykański II, Konstytucje. Dekrety. Deklaracje. Tekst polski. Nowe tłumaczenie, Poznań 2002, nr 39; F. Lambiasi, Lo Spirito Santo: mistero e presenza. Per una sintesi di pneumatologia, Bologna 1987, s. 33on.

8 Zob. M. Łanoszka, Idea odnowienia kosmosu w eschatologicznej doktrynie tradycji synoptycznej i Janowej, Tarnów 2009, s. 53n; W. Hryniewicz, Świadkowie wielkiej nadziei. Zbawienie powszechne w myśli wczesnochrześcijańskiej, Warszawa 2009, s. 222n.

Zob. Jan Paweł II, enc. Dominum et vivificantem o Duchu Świętym w życiu Kościoła i świata, 18.05.1986, nr 50, http://w2.vatican.va/content/john-paul-ii/pl/encyclicals/documents/ hf_jp-ii_enc_18051986_dominum-et-vivificantem.html, 8.o8.2012. 
pełni, gdzie zmartwychwstały Chrystus wszystko ogarnia i oświetla” (Ls, nr 83; zob. też nr 243-244) ${ }^{10}$. W świetle przedstawionych danych do podstawowych cech ludzkiego spotkania z misterium Boga należy doświadczenie Jego bycia Stwórcą i troskliwym Gospodarzem wspólnego domu.

\section{Kryzys ekologiczny: identyfikacja jego przyczyn i tym samym możliwości uporania się z nim}

Człowiek nie może nie oddziaływać na swe środowisko. Dotyczy to także środowiska naturalnego. Jak stwierdza papież Franciszek, ten wpływ nie musi być ani negatywny, ani neutralny. Jeśli ludzka aktywność „zapewnia roztropny rozwój stworzenia”, to jest ona „najbardziej adekwatną formą zatroszczenia się o nie, ponieważ zakłada przyjęcie postawy narzędzia Boga, aby pomagać w wyłanianiu się potencjalności, jakie On sam wypisał w rzeczach" (LS, nr 14) ${ }^{11}$. Kryzys ekologiczny przedstawia się jako szczególnie niebezpieczne współczesne zagrożenie (LS, $\mathrm{nr}$ 3, 25, 32, 57; zob. też nr 4). Winni są tu poszczególni ludzie, ich mniejsze czy większe grupy i społeczności, jak też cała ludzkość (Ls, np. nr 8, 23). Powodem są tutaj zaniedbania ze strony „możnych tego świata”, skutkuje także brak zainteresowania ze strony pozostałych ludzi (Ls, nr 14). Kryzys ekologiczny ,jest ujawnieniem się lub zewnętrznym przejawem” takich bolączek, jak współczesny kryzys kulturowy, etyczny i duchowy (LS, nr 9, 119), w tym obojętności religijnej, wrogości wobec religii i ich potencjału, niewłaściwego rozumienia chrześcijaństwa (LS, nr 62-63) (12 $^{2}$ Innymi słowy, chodzi o błędne rozumienie życia, w tym ludzkiego zaangażowania i działania, na co składa się bezzasadna wiara, że rozwój technologiczny sam w sobie przyniesie rozwiązanie takich czy innych lub wręcz wszystkich problemów (Ls, nr 14). Wśród przyczyn kryzysu ekologicznego należy wymienić: wygodnictwo, obojętność (LS, nr 14), krótkowzroczne pojmowanie „gospodarki i działalności handlowej oraz produkcji” (LS, nr 32; zob. też nr 101), konsumpcjonizm (LS, $\mathrm{nr}$ 55), egoizm (LS, nr 45). Ten ostatni to występek przeciw drugiemu

${ }^{10}$ Zob. D. Edwards, „Sublime Communion”: The Theology of the Natural World in „Laudato si”, „Theological Studies (Online)” 77 (2016) nr 2, s. 377n; R. W. Miller, Deep responsibility for the deep future, "Theological Studies (Online)” 77 (2016) nr 2, s. 445n.

${ }_{11}$ D. P. Castillo, Integral ecology as a liberationist concept, „Theological Studies (Online)” 77 (2016) nr 2, s. 356n.

${ }_{12}$ Zob. N. Niemandt, Ecodomy in mission: the ecological crisis in the light of recent ecumenical statements, „Verbum et Ecclesia” 36 (2015) nr 3, s. 25; J. Łukomski, Próba zbudowania chrześcijańskiej etyki środowiska naturalnego, Kielce 2000, s. 99 n. 
człowiekowi (LS, nr 49) i przeciw innym stworzeniom. Egoizm względem innych stworzeń jest rzadziej dostrzegany czy bardziej lekceważony.

Kościół nie mówi dziś [...], że inne stworzenia są całkowicie podporządkowane dobru człowieka, jak gdyby nie miały one wartości samej w sobie i jakbyśmy mogli nimi dysponować do woli. [...] „, odniesieniu do innych stworzeń można by mówić o priorytecie być przed być użytecznym" [...]. Katechizm kwestionuje bardzo bezpośrednio i zdecydowanie to, co byłoby wypaczonym antropocentryzmem: „Każde stworzenie posiada swoją własną dobroć i doskonałość [...]. Różne stworzenia, [...] w ich własnym bycie, odzwierciedlają, każde na swój sposób, jakiś promień nieskończonej mądrości i dobroci Boga. Z tego powodu człowiek powinien szanować dobroć każdego stworzenia"(LS, $\mathrm{nr} 69)^{13}$.

Kryzys ekologiczny to rezultat braku właściwej kontroli nad ludzkim postępowaniem, nierozważnego korzystania ze środowiska naturalnego (LS, nr 8). Utrwalanie się, a nawet potęgowanie się kryzysu ekologicznego to także wynik rozwijania się takiej ekologii, jaką papież ocenia jako „powierzchowna czy pozorna”, umacniającej „pewną ospałość i bezmyślną nieodpowiedzialność” (LS, nr 59) ${ }^{14}$. Stwórca zwraca się do ludzi, „przemawiając” przez świat stworzony, przez przyrodę (Ls, nr 12, 85, 239). Przyczyna kryzysu ekologicznego tkwi w ludzkim zamknięciu się na to przesłanie. „Brak troski o ograniczenie szkód wyrządzanych przyrodzie oraz konsekwencje ekologiczne decyzji są jedynie widocznym odzwierciedleniem braku zainteresowania tym, by przyjąć orędzie, jakie natura ma wypisane w swoich strukturach" (Ls, nr 117). Chrześcijaństwo udziela tu ważnej, jak najbardziej użytecznej pomocy (por. Ls, nr 199) ${ }^{15}$, bo wskazuje, że w ostatecznym rozrachunku również kryzys ekologiczny stanowi konsekwencję grzechu (por. LS, nr 66). Jest to podstawowe wskazanie, gdy chodzi o całościowe podejście do tego kryzysu, o uporanie się z nim (por. Ls, np. nr 11, 15, 62, 138, 143) ${ }^{16}$. „Uwzględniając złożoność kryzysu ekologicznego i jego wielu przyczyn, musimy uznać, że jeden jedyny sposób interpretowania i przekształcania rzeczywistości nie przynosi rozwiązań" (LS, nr 63). Następnie

${ }_{13}$ Zob. A. Linzey, Teologia zwierząt, tłum. W. Kostrzewski, Kraków 2010, s. 114n.

${ }_{14}$ Zob. J. F. Cassel, Environmental Ethics, Minneapolis 1971, s. 133n.

${ }_{15}$ Zob. Franciszek, enc. Lumen fidei o wierze, 29.06.2013, nr 34, http://w2.vatican.va/content/ francesco/pl/encyclicals/documents/papa-francesco_20130629_enciclica-lumen-fidei.html, 16.03.2016.

${ }^{16}$ Por. J. E. D. Alves, A encíclica „Laudato si”': Ecologia integral, gênero e ecologia profunda, „Horizonte” 13 (2015) nr 13, s. 1315n. 
papież Franciszek wskazuje: „Konieczne jest również odwołanie się do różnorodnego bogactwa kulturowego narodów, sztuki i poezji, do życia wewnętrznego i duchowości. Jeśli naprawdę chcemy budować ekologię pozwalającą nam naprawić to wszystko, co zniszczyliśmy, to nie można pomijać żadnej dziedziny nauki i mądrości, także religijnej, z jej specyficznym językiem. Ponadto Kościół katolicki jest otwarty na dialog z myślą filozoficzną, a to pozwala mu tworzyć różne syntezy wiary i rozumu" (LS, nr 63) ${ }^{17}$.

Skoro kryzys ekologiczny w ostatecznym rozrachunku wynika z ludzkiej grzeszności i tym samym $\mathrm{z}$ negatywnych zmian w relacjach ludzi z Bogiem (por. LS, np. nr 66), to ludzie nie są tu jedynymi winnymi. Zarazem mamy wskazanie, że duchowość posiada podstawowe znaczenie, by uporać się z tym kryzysem, oraz że przezwyciężanie go wpisuje się w realizację dzieła stworzenia-zbawienia (por. Ls, np. nr 100, 243). W takim właśnie kontekście papież Franciszek wymienia szereg pozytywnych przykładów. Powołuje się parę razy na czczonych w Kościele katolickim z okresu starożytności: św. Justyna (por. Ls, przyp. 80), św. Bazylego Wielkiego (por. Ls, np. nr 77), św. Wincentego z Lerynu (por. Ls, przyp. 98), ze średniowiecza św. Franciszka z Asyżu (por. Ls, np. nr 1) i kilka razy na św. Tomasza $z$ Akwinu (por. Ls, np. nr 86) oraz św. Bonawenturę (por. LS, np. nr 11), a także żyjącego w XVI w. św. Jana od Krzyża (por. Ls, nr 23). Około 40 razy papież Franciszek powołuje się na św. Jana Pawła II (por. Ls, np. nr 5), kilka razy na bł. Pawła vi (por. LS, np. nr 4) ${ }^{18}$. Papież Benedykt XVI został wymieniony ok. 30 razy (por. Ls, np. nr 6). Mamy też kilka odniesień do Soboru Watykańskiego II (por. np. Ls, nr 80), do Katechizmu Kościoła Katolickiego (por. Ls, np. nr 69), ponad 15 razy do nauczania katolickich episkopatów lokalnych (por. Ls, np. nr 85), ok. 10 do Papieskiej Rady Iustitia et Pax (por. Ls, np. nr 50). Został wymieniony katolicki średniowieczny świecki poeta Dante Alighieri (por. Ls, nr 77), z prawie współczesnych katolickich czy szerzej związanych z chrześcijaństwem myślicieli znanych na forum światowym - kilka razy Romano Guardini (por. Ls, np. nr 203), jeden raz o. Pierre Teilhard de Chardin (por. Ls, przyp. 53), jeden raz protestant Paul Ricoeur (por. Ls, przyp. 59). Parę razy został wymieniony współczesny patriarcha prawosławny Bartłomiej I (por. Ls, np. nr 7). Jeden raz mamy odniesienie, i to pozytywne, do przedstawiciela sufizmu Ali Al-Khawwasa (por. Ls, przyp. 159). W skazane przykłady są istotne

${ }_{17}$ Zob. C. Z. Peppard, Hydrology, theology, and „Laudato si”, „Theological Studies (Online)” $77(2016) \mathrm{nr} 2$, s. 421n; C. E. Deane-Drummond, „Laudato si”' and the natural sciences: An assessment of possibilities and limits, „Theological Studies (Online)” 77 (2016) nr 2, s. 395n.

${ }_{18}$ Zob. np. E. Osek, Przyroda w pismach Bazylego Wielkiego, Lublin 2009, s. 17on. 
m.in. z tego powodu, że kwestia ekologiczna, pozytywny stosunek do innych niż ludzie stworzeń zamieszkujących Ziemię, wydaje się współcześnie postrzegana i przestawiana $\mathrm{w}$ dużym uproszczeniu jako tak w przeszłości, jak i obecnie - obca religiom (może nawet $z$ konotacją, że mamy do czynienia $\mathrm{z}$ ich strony nie tylko z obojętnością, ale wręcz z wrogością), zwłaszcza chrześcijaństwu (por. LS, nr 67), za wyjątkiem św. Franciszka z Asyżuª ${ }^{19}$. W świetle Laudato si takie stanowisko okazuje się błędne, a encyklika może przyczynić się do przezwyciężenia uprzedzeń czy bezpodstawnych oskarżeń.

\section{Przezwyciężenie kryzysu ekologicznego: niezbędna pomoc ze strony duchowości}

Papież Franciszek w Laudato si' postrzega współczesność następująco: ludzkość teraz żyje w epoce postmodernistycznego zamieszania. Nie potrafi ona dojść do „nowego zrozumienia samej siebie”. Brakuje jej ukierunkowania. Trudności dotyczą ludzkiej tożsamości i to ludzkość dręczy. Boleśnie daje się we znaki rozdarcie: mamy „zbyt wiele środków” w stosunku do „niewielkich i rachitycznych aspiracji” (Ls, nr 203). Wskazane problemy są związane z duchowością. Ona sama jest niedoceniana czy też mylnie rozumiana ${ }^{20}$. Podstawowe przyczyny kryzysu ekologicznego mają charakter duchowy, są związane z duchowością: jeśli się tego nie uwzględni, to stawiając czoła kryzysowi ekologicznemu, „zmagać się będziemy jedynie z objawami” (Ls, nr 9; zob. też nr 66) ${ }^{21}$. „[...] wolność ulega wypaczeniu, kiedy powierza się ją ślepym siłom podświadomości, doraźnym potrzebom, egoizmowi i brutalnej przemocy. W tym sensie jest zagrożona i bezbronna wobec swojej własnej mocy, która nieustannie rośnie, nie mając właściwych narzędzi jej kontroli. Może dysponować powierzchownymi mechanizmami, niemniej należy stwierdzić, że brak jej dziś odpowiednio solidnej etyki, kultury i duchowości” (LS, nr 105). Papież Franciszek czyni też swoimi słowa swego poprzednika: „Na świecie jest coraz

19 Zob. J. Zizioulas, A comment on Pope Francis' encyclical „Laudato si”, „The Greek Orthodox Theological Review" 60 (2015) nr 3-4, s. 189n; X. J. Zhang, How St. Francis influenced Pope Francis's „Laudato si”, „Cross Currents” 66 (2016) nr 1, s. 45n.

${ }^{20}$ Zob. Franciszek, Spotkanie z polskimi biskupami, [w:] Homilie i przemówienia Ojca Świętego Franciszka wygłoszone podczas wizyty w Polsce (27-31.07.2016), http://episkopat.pl/sdm-2016wystapienia-ojca-swietego, 28.01.2017.

${ }^{21}$ Zob. też Franciszek, lettera per l'istituzione della Giornata Mondiale di Preghiera per la Cura del Creato, 6.08.2015, http://w2.vatican.va/content/francesco/it/letters/2015/documents/ papa-francesco_20150806_lettera-giornata-cura-creato.html, 20.11.2016. 
więcej [...] zewnętrznych pustyń, ponieważ pustynie wewnętrzne stały się tak rozległe" (LS, nr 217). Od duchowości zależy pomyślność tak eschatologiczna, jak i doczesna ${ }^{22}$.

Papież Franciszek wskazuje, że do duchowości należy podchodzić całościowo: tak do jej znaczenia, jak i zakresu składających się na nią relacji. „[...] ludzka egzystencja opiera się na trzech podstawowych relacjach ściśle ze sobą związanych: na relacji z Bogiem, z innymi ludźmi i z ziemią"23 - takie wskazanie jest ważne m.in. ze względu na znane współcześnie przeciwstawianie sobie duchowości i religii. Następnie papież Franciszek wyjaśnia: „te trzy istotne relacje uległy zerwaniu nie tylko zewnętrznie, ale również w nas samych. Tym zerwaniem jest grzech. Harmonia między Stwórcą, ludzkością a całym stworzeniem została zniszczona, ponieważ człowiek usiłował zająć miejsce Boga, odmawiając uznania siebie za ograniczone stworzenie. Fakt ten wypaczył także naturę przykazania, by «panować» nad ziemią [...] oraz «uprawiać ją i doglądać jej»" (Ls, nr 66) ${ }^{24}$. Potrzebna jest więc przemiana duchowa, metanoia w znaczeniu, jak to sugeruje np. etymologia tego terminu, nie tylko oczyszczenia, ale i rozwoju, kierowania się coraz bardziej dobrem wspólnym, otwarcia się na innych przez dialog, „cierpliwości, ascezy i wielkoduszności” (LS, nr 201). Duchowość nie ma tu wypierać innych wymiarów ludzkiej aktywności, lecz wpisać się harmonijnie w jej całość. Tak można rozumieć to, co papież pisze o kulturze ekologicznej. Ma ona być „innym spojrzeniem, myślą, polityką, programem edukacyjnym, stylem życia i duchowości, które nadawałyby kształt sprzeciwowi wobec ekspansji paradygmatu technokratycznego" (LS, nr 111). Wspomniany rozwój oraz podejście całościowe w ostatecznym rozrachunku mają też następujące kardynalne cechy: chodzi o przyjęcie działania Bożego, trynitarnego, udział w nim, skorzystanie z jego mocy,

${ }_{22}$ Zob. M. Carbajo Núñez, Global ethical challenges in the light of the encyclical „Laudato si"' and the Jubilee of Mercy, „Antonianum” 91 (2016) nr 2, s. 335n; L. Galleni, Postazione: scienza-e-teologia, il progetto del terzo millenio, [w:] Lo Spirito Creatore e la novità del cosmo, a cura di V. Maraldi, Milano 2002, s. 279.

${ }_{23}$ Zob. np. J. Mariański, Sekularyzacja, desekularyzacja, nowa duchowość. Studium socjologiczne, Kraków 2013, s. 113n.

${ }^{24}$ Zob. Franciszek, Messaggio per la celebrazione della Giornata Mondiale di Preghiera per la Cura del Creato, $\mathrm{nr}$ 2, 6.08.2016, http://w2.vatican.va/content/francesco/pl/messages/pontmessages/2016/documents/papa-francesco_20160901_messaggio-giornata-cura-creato.html, 5.11.2016; J. B. Green, Death of Christ, [w:] Dictionary of Paul and His Letters, eds. G. F. Hawthorne et al., Downers Grove-Leicester 1993, s. 206; A. Llano, El cuidado de la naturaleza, refugio viviente, „Scripta Theologica” 48 (2016) nr 2, s. 439n. 
upodobnienie-naśladowanie Osób Bożych. „Wszystko jest połączone, a to nas zachęca do dojrzewania w duchowości globalnej solidarności, która emanuje z tajemnicy Trójcy Świętej” (LS, nr 241) ${ }^{25}$. W świetle poniżej przytoczonych słów termin „emanuje” trzeba rozumieć jako już zapoczątkowany, skuteczny proces: „W każdym stworzeniu zamieszkuje Jego ożywiający Duch, który nas wzywa do relacji z Nim [...]. Odkrycie tej obecności pobudza w nas rozwój "cnót ekologicznych»" (LS, nr 88; zob. nr 225). Taki tok nauczania rzuca bardzo ważne światło na przesłanie, że to właściwe relacje z Bogiem są warunkiem, by relacje $z$ innymi układały się pomyślnie. „Najlepszym sposobem postawienia człowieka na właściwym mu miejscu i skończenia z jego roszczeniami do bycia absolutnym władcą ziemi jest ponowne przypomnienie postaci Ojca Stworzyciela i jedynego Pana świata" (Ls, nr 75). Korekta ludzkiej duchowości nie jest tu np. karą na zasadzie rewanżu za popełniony błąd, lecz otwarciem na naprawę i na nowe, wspaniałe możliwości.

Duchowość posiada duże znaczenie praktyczne: również dla pomyślnego kształtowania doczesności. Odgrywa niezastąpioną rolę, gdy chodzi o skuteczne stawienie czoła kryzysowi ekologicznemu. Oczywiście jednym z zasadniczych warunków jest, by duchowość poprawnie rozumieć, kształtować ją. Błędy po stronie chrześcijan czy po stronie innych ludzi mogą tutaj skutkować mylną oceną chrześcijaństwa i tym samym prowadzić do niewykorzystania właściwego mu wielkiego potencjału duchowego (zob. np. Ls, nr 67). Papież Franciszek wskazuje na następujące kierunkowanie działań: „Nie uciekamy od świata ani nie zaprzeczamy naturze, kiedy chcemy spotykać się z Bogiem” $(\mathrm{LS}, \mathrm{nr} 235)^{26}$. Encyklika przedstawia korektę i kierunek rozwoju duchowości chrześcijańskiej.

[...] niektórzy zaangażowani chrześcijanie i ludzie modlitwy pod pretekstem realizmu i pragmatyzmu często drwią z troski o środowisko naturalne. Inni są bierni, niechętnie zmieniają swoje przyzwyczajenia i stają się niespójni wewnętrznie. Brakuje im zatem nawrócenia ekologicznego, które wiąże się z rozwijaniem wszystkich konsekwencji ich spotkania z Jezusem w relacjach z otaczającym ich światem. Życie powołaniem, by być obrońcami dzieła Bożego, jest istotną częścią

${ }_{25}$ Zob. R. Marx, „Everything is connected”: On the relevance of an integral understanding of reality in "Laudato si”, "Theological Studies (Online)” 77 (2016) nr 2, s. 30on.

${ }^{26}$ Co do problemów, w tym błędów, związanych z koncepcją „ucieczki ze/od świata”, zob. F. Sesé, Fuga mundi, [w:] Dizionario enciclopedico di spiritualità, t. 2, a cura di E. Ancilli et al., Roma 1992, s. 1062 n. 
życia uczciwego, nie zaś czymś opcjonalnym, ani też drugorzędnym elementem doświadczenia chrześcijańskiego (LS, nr 217).

Także troska, życzliwość wobec innych niż ludzie stworzeń wpisują się realizację ludzkiego podobieństwa do Boga, naśladowania Jego, jak również ludzi, którzy najbardziej się do Niego zbliżyli (por. Ls, nr 240, 10). W ten sposób człowiek rozwija się w skali, która chyba zbyt często pozostaje niedostrzeżona.

Byt ludzki [...] tym bardziej się rozwija, tym bardziej dojrzewa i tym bardziej się uświęca, im bardziej wchodzi w relacje, przekraczając siebie, aby żyć w komunii z Bogiem, z innymi i ze wszystkimi stworzeniami. W ten sposób przyjmuje w swoim życiu ową dynamikę trynitarną, jaką Bóg w nim odcisnął od począt$\mathrm{ku}$ jego istnienia. Wszystko jest połączone, a to nas zachęca do dojrzewania w duchowości globalnej solidarności, która emanuje z tajemnicy Trójcy Świętej (LS, nr 240).

Laudato si podejmuje także mający ogromny pozytywny dorobek temat naśladowania Chrystusa, uświadamiając, że posiada on także następujący wymiar. Grzech negatywnie wpływa m.in. na relacje człowieka z innymi stworzeniami. Nawrócenie zaś jako wynik współdziałania boskiego i ludzkiego, będąc naśladowaniem Chrystusa, także dotyczy uzdrowienia i pozytywnego rozwoju relacji między ludźmi i innymi stworzeniami.

Różne treści naszej wiary [...] pomagają ubogacić sens tego nawrócenia [...]. Kiedy czytamy w Ewangelii, jak Jezus mówi o ptakach, że „żaden z nich nie jest zapomniany w oczach Bożych" (Łk 12, 6), to czy będziemy zdolni do znęcania się nad nimi i wyrządzania im zła? Zachęcam wszystkich chrześcijan, aby ukazali jasno ten wymiar swojego nawrócenia, pozwalając, by moc i światło otrzymanej łaski obejmowały także relacje $\mathrm{z}$ innymi istotami i otaczającym światem, budząc owo cudowne braterstwo z całym stworzeniem (LS, nr 221).

Chrystus, który podziwiał przyrodę, „może nas nauczyć troski, motywować nas do wielkodusznej pracy z czułością, aby chronić ten świat, jaki powierzył nam Bóg" (LS, nr 242). Papież przez swe nauczanie prowadzi do oczyszczenia z nieporozumień i przyzwyczajeń pojmowanie ascezy. Już gr. $\alpha \sigma \kappa^{\circ} \sigma \iota \sigma$ wskazuje na zaangażowanie się, by dojść do doskonałości. Papież Franciszek pisze, że patriarcha Bartłomiej wysunął propozycję, „byśmy przeszli od konsumpcji do poświęcenia, od chciwości do wielkoduszności, od marnotrawstwa do zdolności 
dzielenia się, do ascezy, która «oznacza uczenie się dawania, a nie po prostu rezygnowania»" (LS, nr 9). Na dążenie do świętości, do doskonałości składa się rezygnacja „czynienia z rzeczywistości jedynie przedmiotu użytku i panowania” (LS, nr 11). Ważnym elementem promowanej w Laudato si' duchowość jest aktywność ludzka rozumiana jako współdziałanie człowieka z Bogiem (zob. np. 1 Kor 15, 10; Ls, nr 80), w tym troska o samą duchowośćc ${ }^{27}$. Kierunek wskazuje m.in. nauczanie papieskie poświęcone nawróceniu ekologicznego i duchowości ekologicznej. O tym, że to ukierunkowanie jest istotne, pokazuje fakt, iż duchowości ekologicznej został poświęcony rozdział vi encykliki, czyli numery 202-245, z wyodrębnieniem tematu nawrócenia ekologicznego jako podrozdziału składającego się na numery 216-221.

„Kryzys ekologiczny jest wezwaniem do głębokiego wewnętrznego nawrócenia" (LS, nr 217) 2 $^{28}$. Nawrócenie to jest rozumiane pozytywnie - mamy do czynienia z korektą względem potocznego, zubożonego rozumienia nawrócenia. Korekta ta odpowiada np. koncepcji metanoi jako osiągnięcia wyższego poziomu świadomości, miłości, istnienia, nie zaś powrotu do choćby najlepszego stanu z przeszłości ${ }^{29}$. Papież pisze tu o rozwijaniu udzielonych przez Boga zdolności. Jest to promowanie entuzjazmu, kreatywności, ducha ofiarowania się Bogu w sposób Jego godny, przyjemny dla Niego (LS, nr 220) ${ }^{30}$. Mamy tutaj zbieżność ze słowami: „Świat to coś więcej niż problem do rozwiązania, jest radosną tajemnicą, którą podziwiamy w zachwycie, oddając chwałę Bogu" (Ls, nr 12). Duchowość ekologiczna to udostępnianie wielkich i cennych zasobów „duchowości chrześcijańskiej, wypracowanej w ciągu dwudziestu wieków doświadczeń osobistych i społecznych, stanowi wspaniały wkład, jaki można wnieść w wysiłek odnowienia ludzkości" (Ls, nr 216). To udostępnianie nie ogranicza się do teorii, do informowania, lecz jest formowaniem, pomocą, współdziałaniem:

${ }_{27}$ Zob. J.-M. Maldamé, Lencyclique du pape François sur l'écologie une clarification et une invitation a agir, „Bulletin de Littérature Ecclésiastique” 117 (2016) nr 2, s. 46n.

${ }^{28}$ Podejmując zagadnienie nawrócenia ekologicznego, papież Franciszek nawiązuje do mało znanego, a przecież obecnego w niejednym dokumencie, wątku składającego się na nauczanie Jana Pawła II (por. Ls, nr 5).

${ }_{29}$ Zob. np. W. Misztal, Duchowość chrześcijan w świetle listów Pawłowych. Związki z Bogiem, Kraków 2010, s. 61n.

${ }^{30}$ Zob. N. Ormerod, C. Vanin, Ecological conversion: What does it mean?, „Theological Studies (Online)" 77 (2016) nr 2, s. 328n; T. S. Albareda, Aportaciones de la „Laudato si” en el contexto de la Agenda 2030 para el Desarrollo Sostenible, „Scripta Theologica” 48 (2016) nr 2, s. 446n. 
Chodzi nie tyle o mówienie o ideach, ile przede wszystkim o motywacje wypływające z duchowości, aby umacniać pasję na rzecz troski o świat. Nie będzie bowiem możliwe zaangażowanie w rzeczy wielkie jedynie w oparciu o wspaniałe doktryny, bez pewnej mistyki, zachęcającej nas, bez „wewnętrznego poruszenia dającego impuls, motywującego, dodającego odwagi i nadającego sens działalności osobistej i wspólnotowej" (LS, nr 216).

Mając na uwadze radzenie sobie z kryzysem ekologicznym, Laudato si proponuje, by skorzystać z potencjału znanych, tradycyjnych, sprawdzonych w ciągu wieków wymiarów duchowości chrześcijańskiej, jak otwarcie się na łaskę Bożą, współdziałanie z nią (por. LS, nr 245), doświadczenie głębokiej i trwałej radości i pogody ducha, wolność od zachłanności, spójność wewnętrzna, docenianie każdej chwili, wszystkiego, spełnienie osobiste (por. Ls, nr 222), modlitwa, w tym dziękczynna, jako wyraz jedności, wdzięczności, solidarności (por. Ls, nr 169, 227), świętowanie niedzieli wraz z uczestnictwem w Eucharystii jako możliwość „uzdrowienia relacji człowieka z Bogiem, z samym sobą, z innymi i ze światem”, który to dzień papież Franciszek przedstawiam jako porękę „ostatecznego przemienienia całej rzeczywistości stworzonej” (LS, nr 237), sumienna realizacja swej pracy, wszystkich swych obowiązków (por. Ls, nr 80, $127,132,232)^{31}$.

W świetle Laudato si duchowość, rozumiana jako relacje z Bogiem i z otoczeniem, jako dokładanie starań o nadanie właściwego kształtu ludzkim relacjom z Bogiem i bliźnimi, stanowi podstawę dla uporania się z kryzysem ekologicznym, dla udanego ludzkiego współdziałania w trosce o wspólny doczesny dom (por. Ls, np. nr 63, 216, 222). Jako wyraz miłości na duchowość składa się tu otwarcie się na Boga i na inne byty, m.in. nawrócenie, asceza, wzrost duchowy, naśladowanie Chrystusa, współdziałanie z Bogiem i z innymi, solidarność, modlitwa. Papież Franciszek pokazuje, że jeśli korzystamy z potencjału duchowości, jest w stanie urzeczywistnić się następujący proces: „jesteśmy wezwani, aby być narzędziami Boga Ojca, żeby nasza planeta była

${ }^{31}$ Zob. G. Moore, Let justice find a voice: Reflections on the relationship between worship and justice, „Worship” 90 (2016) nr 3, s. 206n; R. Nęcek, Edukacja medialna w nauczaniu społecznym papieża Franciszka, wprowadzenie kard. L. H. Villalba, Kraków 2016, s. 43n. 
tym, co On wymarzył, stwarzając ją, i by odpowiadała na Jego projekt pokoju, piękna i pełni” (LS, nr 50).

\section{ABstrakT}

Opracowanie prezentuje związki między kryzysem ekologicznym a duchowością chrześcijańską w ujęciu encykliki Laudato si’ papieża Franciszka. Zwrócono uwagę na przedstawioną $\mathrm{w}$ tym dokumencie koncepcję Boga jako Stwórcy oraz zarazem troskliwego Gospodarza i Opiekuna doczesnego świata. Podjęto kwestię zidentyfikowanych w Laudato si przyczyn obecnego kryzysu ekologicznego. Dane te stanowią podstawę dla prezentacji przesłania o pozytywnym potencjale właściwym duchowości chrześcijańskiej, wręcz o jej niezbędności, by skutecznie stawić czoło kryzysowi ekologicznemu.

\section{SŁOWA KLUCZOWE}

chrześcijaństwo, duchowość, ekologia, kryzys ekologiczny, papież Franciszek

\section{Abstract}

\section{The necessity of the spirituality to face the ecological} crisis: the message of the encyclical letter Laudato si' The article concerns, according to the Pope's Francis encyclical letter Laudato si', the relations between the Christian spirituality and the ecological crisis. It presents the concept of God as the Creator and at the same time the caring Host-Tutor of the world. The second thematic area concerns the indicated in the encyclical letter Laudato si' causes of the contemporary ecological crisis. These data are the basis for the presentation of the positive potential of Christian spirituality, even its necessity to successfully confront the ecological crisis.

\section{KEY WORDS}

Christianity, ecological crisis, ecology, Pope Francis, spirituality

\section{Bibliografia}

Albareda T. S., Aportaciones de la „Laudato si”" en el contexto de la Agenda 2030 para el Desarrollo Sostenible, „Scripta Theologica” 48 (2016) nr 2, s. 443-462.

Alves J. E. D., A encíclica „Laudato si”': ecologia integral, gênero e ecologia profunda, „Horizonte” 13 (2015) nr 13, s. 1315-1344. 
Benedykt xvi, Katecheza, 9.11.2005, [w:] „L'Osservatore Romano” (wyd. pol.) 27 (2006) nr 3, s. 39-40.

Arand C. P., Tending our common home: Reflections on „Laudato si”, „Concordia Journal" 41 (2015) nr 4, s. 307-318.

Byrne B., A Pauline Complement to „Laudato si”, „Theological Studies (Online)” 77 (2016) nr 2, s. 308-327.

Cantalamessa R., Pieśń Ducha Świętego. Rozważania na temat „Veni Creator”, tłum. M. Przeczewski, Warszawa 2003.

Carbajo Núñez M., Global ethical challenges in the light of the encyclical „Laudato si” and the Jubilee of Mercy, „Antonianum” 91 (2016) nr 2, s. 333-36o.

Cassel J. F., Environmental Ethics, Minneapolis 1971.

Castillo D. P., Integral ecology as a liberationist concept, „Theological Studies (Online)” 77 (2016) $\mathrm{nr} 2$, s. 353-376.

Deane-Drummond C. E., „Laudato si” and the natural sciences: An assessment of possibilities and limits, „Theological Studies (Online)” 77 (2016) nr 2, s. 392-415.

Edwards D., „Sublime communion”: The theology of the natural world in "Laudato si”, ,"Theological Studies (Online)" 77 (2016) nr 2, s. 377-391.

Franciszek, enc. Laudato si' poświęcona trosce o wspólny dom, 24.05.2015, https:// w2.vatican.va/content/dam/francesco/pdf/encyclicals/documents/papa-francesco_20150524_enciclica-laudato-si_pl.pdf.

Franciszek, lettera per l'istituzione della Giornata Mondiale di Preghiera per la Cura del Creato, 6.08.2015, http://w2.vatican.va/content/francesco/it/letters/2015/documents/papa-francesco_20150806_lettera-giornata-cura-creato.html.

Franciszek, enc. Lumen fidei o wierze, 29.06.2013, http://w2.vatican.va/content/francesco/pl/encyclicals/documents/papa-francesco_20130629_enciclica-lumen-fidei. html.

Franciszek, Messaggio per la celebrazione della Giornata Mondiale di Preghiera per la Cura del Creato, 6.08.2016, http://w2.vatican.va/content/francesco/pl/messages/ pont-messages/2016/documents/papa-francesco_20160901_messaggio-giornatacura-creato.html.

Franciszek, Spotkanie z polskimi biskupami, [w:] Homilie i przemówienia Ojca Świętego Franciszka wygłoszone podczas wizyty w Polsce (27-31.07.2016), http://episkopat. $\mathrm{pl} / \mathrm{sdm}$-2016-wystapienia-ojca-swietego.

Jan Paweł II, enc. Dominum et vivificantem o Duchu Świętym w życiu Kościoła i świata, 18.05.1986, http://w2.vatican.va/content/john-paul-ii/pl/encyclicals/documents/ hf_jp-ii_enc_18051986_dominum-et-vivificantem.html.

Galleni L., Postazione: scienza-e-teologia, il progetto del terzo millenio, [w:] Lo Spirito Creatore e la novità del cosmo, a cura di V. Maraldi, Milano 2002, s. 249-279. 
Green J. B., Death of Christ, [w:] Dictionary of Paul and His Letters, eds. G. F. Hawthorne et al., Downers Grove-Leicester 1993, s. 201-209.

Jenkins W., Ecologies of Grace: Environmental Ethics and Christian Theology, Oxford 2013.

Hryniewicz W., Świadkowie wielkiej nadziei. Zbawienie powszechne w myśli wczesnochrześcijańskiej, Warszawa 2009.

Katechizm Kościoła Katolickiego, Poznań 2002.

Lambiasi F., Lo Spirito Santo: mistero e presenza. Per una sintesi di pneumatologia, Bologna 1987.

Linzey A., Teologia zwierząt, tłum. W. Kostrzewski, Kraków 2010.

Llano A., El cuidado de la naturaleza, refugio viviente, „Scripta Theologica” 48 (2016) nr 2, s. 429-441.

Lubomirski M., Il ruolo dello Spirito Santo nel passaggio dall'uomo vecchio alluomo nuovo secondo san Paolo, Roma 1988.

Łanoszka M., Idea odnowienia kosmosu w eschatologicznej doktrynie tradycji synoptycznej i Janowej, Tarnów 2009.

Łukomski J., Próba zbudowania chrześcijańskiej etyki środowiska naturalnego, Kielce 2000.

Maldamé J.-M., L'encyclique du pape François sur lécologie. Une clarification et une invitation a agir, „Bulletin de Littérature Ecclésiastique” 117 (2016) nr 2, s. 43-67.

Maraldi V., Lo Spirito Creatore e la novità del cosmo. Postfazione di L. Galleni, Milano 2002.

Mariański J., Sekularyzacja, desekularyzacja, nowa duchowość. Studium socjologiczne, Kraków 2013.

Marx R., „Everything is connected”: On the relevance of an integral understanding of reality in "Laudato si”, „Theological Studies (Online)” 77 (2016) nr 2, s. 295-307.

Miller R. W., Deep responsibility for the deep future, „Theological Studies (Online)" 77 (2016) nr 2, s. 436-465.

Misztal W., Duchowość chrześcijan w świetle listów Pawłowych. Związki z Bogiem, Kraków 2010.

Moore G., Let justice find a voice: Reflections on the relationship between worship and justice, „Worship” 9o (2016) nr 3, s. 206-224.

Nęcek R., Edukacja medialna w nauczaniu społecznym papieża Franciszka, wprowadzenie kard. L. H. Villalba, Kraków 2016.

Niemandt N., Ecodomy in mission: the ecological crisis in the light of recent ecumenical statements, „Verbum et Ecclesia” 36 (2015) nr 3, s. 21-45.

Ormerod N., Vanin C., Ecological conversion: What does it mean?, „Theological Studies (Online)" 77 (2016) nr 2, s. 328-352. 
Osek E., Przyroda w pismach Bazylego Wielkiego, Lublin 2009.

Peppard C. Z., Hydrology, theology, and „Laudato si”, „Theological Studies (Online)” 77 (2016) nr 2, s. 416-435.

Sesé F., Fuga mundi, [w:] Dizionario enciclopedico di spiritualità, t. 2, a cura di E. Ancilli et al., Roma 1992, s. 1062-1065.

Sobór Watykański II, konst. duszpasterska Gaudium et spes o Kościele w świecie współczesnym, 7.12.1965, [w:] Sobór Watykański II. Konstytucje. Dekrety. Deklaracje. Tekst polski. Nowe tłumaczenie, Poznań 2002, s. 526-606.

Zhang X. J., How St. Francis influenced Pope Francis's „Laudato si”, „Cross Currents” 66 (2016) nr 1, s. 42-56.

Zizioulas J., A comment on Pope Francis' encyclical „Laudato si”, „The Greek Orthodox Theological Review" 6o (2015) nr 3-4, s. 184-191. 